\title{
Pastoral Womanscapes (Baudelaire, Tournier, Jablonka)
}

'The discourse of man is in the metaphor of woman.'1

-Gayatri Spivak.

\section{Womanscape}

Despite but also precisely because of the locus amoenus it posits, far removed from the harsh realities of the city, the pastoral is an ideologically saturated genre. Critics as varied as William Empson, Raymond Williams and Michael Bennett have already demonstrated its productive potential for thinking about matters pertaining to class ${ }^{2}$ and race. ${ }^{3}$ In exploring how literary texts frequently mediate man's relationship to the

${ }^{1}$ Gayatri Spivak, 'Displacement and the Discourse of Woman,' in Displacement: Derrida and After, ed. by Mark Krupnick (Bloomington: Indiana University Press, 1983, pp. 169-95), p. 169.

${ }^{2}$ William Empson, Some Versions of Pastoral: A Study of the Pastoral Form in Literature (London: Penguin, 1935, repr. 1995). Empson intends to reclaim the pastoral as Proletarian art by conceiving of the genre as a device that clarifies and enlarges our understanding of the class struggle. Raymond Williams also underlines the power differential at the heart of the genre: pastoral poems, he writes, 'are not country life but social compliment; the familiar hyperboles of the aristocracy and its attendants.' [Raymond Williams, The Country and the City (London: Vintage, 1973, repr. 2016), p. 47.]

${ }^{3}$ In his essay on the African-American writer and abolitionist Frederick Douglass, Bennett notes that ' $[t]$ he definition of the slave as property makes it difficult for Douglass to have a positive relationship with the Southern landscape since he is legally part of that landscape.' [Michael Bennett, 'Anti-Pastoralism, Frederick Douglass, and the Nature of Slavery', in Beyond Nature Writing. Expanding the 
environment by relocating and recasting Nature in the female form — a rhetorical move that Annette Kolodny has dubbed the 'male pastoral impulse' ${ }^{4}$ — I wish to turn my attention here to the role that gender plays in the genre. Its yoking together of Nature and the feminine typically presents a chiastic structure that maps woman onto landscape while landscape takes on a markedly 'feminine' aspect. It would seem that images of bountiful lands and female bodies have forever been intertwined: to wit, the Biblical Song of Songs in which the bride’s tenderly listed physical attributes summon forth the vision of a lush, secret garden.

The projection of human anatomy onto the natural world can be discerned in the words we use to describe it. In English we speak of the foot of a hill, a body of water or the mouth of a river. But this metonymical operation is more obvious, and more obviously feminised, in the French language, where the word bassin means both basin and pelvis, mamelon (nipple) is also a synonym for butte or hillock, and gorge refers not only to a ravine but to a woman's breasts (the word soutien-gorge is a vestige of this older usage). At the same time, the spurious paradigm of male agency and female passivity is brought to bear upon the geographical imaginary. Rebecca Solnit is quick to point out, for example, how records of mountaineers' first ascents

Boundaries of Ecocriticism, ed. by Armbruster and Wallace (Charlottesville: University of Virginia Press, 2001), pp. 195-210 (p. 200).]

${ }^{4}$ In The Lay of the Land: Metaphor as Experience and History in American Life and Letters (Chapel Hill: University of North Carolina Press, 1975), Annette Kolodny considers the systematic elision between land and woman in the accounts of American settlers. See also Gillian Rose’s Feminism \& Geography: The Limits of Geographical Knowledge (Cambridge: Polity Press, 1993), especially chapter 5, 'Looking at Landscape: The Uneasy Pleasures of Power,' pp. 86-112. 
are couched in a 'vocabulary of virginity, penetration, defloration, and possession [that is] transplanted to-or replanted in —-the landscape. ${ }^{5}$ This dynamic sheds light on the recurrent slippages that postcolonial theorists have identified, in Orientalist discourse, between the colony and the female body. ${ }^{6}$ Hence Assia Djebar, in her brilliant 1985 novel L'amour, la fantasia, teases out in the historical accounts of the 1830 conquest of Algeria the manifold ways in which the French conquest was framed in terms of a perverse romance plot, leading to the seduction, ravishment and subjugation of a coyly alluring fiancée named Algiers.

This fantasied natural landscape, in which woman repeatedly and insistently serves as ground to man's figure, constitutes one of the founding tropes of the pastoral. It also animates the three otherwise very diverse works I engage here: Charles Baudelaire’s poem ‘La géante’ from Les Fleurs du mal (1857), Michel Tournier’s bestselling 1967 novel Vendredi ou les limbes du Pacifique, and Ivan Jablonka’s Médicis prize-winning book Laëtitia ou la fin des hommes from 2016.

\footnotetext{
${ }^{5}$ Rebecca Solnit, As Eve Said to the Serpent: On Landscape, Gender and Art (Athens: University of Georgia Press, 2001; ${ }^{\text {nd }}$ ed. 2003), p. 202. In a similar vein (and seemingly making a virtue out of necessity), ecofeminist thinkers and activists have linked the plundering and pillaging of Earth's resources — the rape of the land, so to speak — to the oppression of women and minorities. A common strategy involves reclaiming, via the insurgent 'queering' of its two terms, the conflation of woman and nature. See Stacey Alaimo, Undomesticated Ground: Recasting Nature as Feminist Space (Ithaca and London: Cornell University Press, 2000).

${ }^{6}$ Among these is Anne McClintock, who develops Edward Said's insights into the question. See in particular her book Imperial Leather: Race, Gender and Sexuality in the Colonial Conquest (New York: Routledge, 1995).
} 
Whilst not belonging, strictly speaking, to the pastoral genre, each of these texts mobilises its commonplace of womanscape in thought-provoking ways. Drawing on the work of feminist theorists Luce Irigaray and Teresa de Lauretis among others, I want to examine how this pervasive topos has enabled writers past and present to think about gender, nature, and how we carve up the spaces we inhabit.

\section{The Woman-Mountain}

Of the countless poets who exploit this trope in their work, few have done so more arrestingly than Charles Baudelaire. That 'first poet of modernity,' as Walter Benjamin would have it, had much to say about the disappearance of the pastoral in $19^{\text {th }}$-century Paris, and the urban landscape that emerges in his work is a space of profound dissonance. In the 'Tableaux parisiens' and especially in the prose poems that make up Le Spleen de Paris, we are led to perceive a radically transformed metropolis in which the very notion of poetry is thrown into crisis. The bustling crowds and the din of traffic seem continually to assault the poet's senses, fragment his voice and fracture his identity, ultimately threatening the harmonic possibilities of the lyric form. In the 'eclogue' composed from his attic perch in 'Paysage,' he strains to keep the city’s workshops, its rivers of coal (fleuves de charbon) and the amorphous yet hypostasised 'Riot, thundering vainly at [his] window' (L'Émeute, tempêtant vainement à ma vitre) from encroaching upon his imaginary bucolic retreat. Today's readers of $19^{\text {th }}$-century French poetry might be tempted therefore to set up a tidy opposition between city and countryside, whereby the relentless, dehumanising march of progress supplanted the simple, unalloyed pleasures of nature. Any such 'before-and-after' narrative is perforce reductive: Romantic representations of idyllic nature, to say nothing of 'Nature' itself, are an artificial construct cobbled together retrospectively from well within the city walls. Or to invert the terms of Adam 
Phillips' phrase, nature might be better defined here as that 'bit of culture that we agree to call nature. ${ }^{7}$

In this story about the alienation of modern consciousness and its inexorable exile from Nature, woman plays a crucial, albeit often occluded, role. For woman herself comes to stand in for the long-lost natural world. ${ }^{8}$ She becomes, in other words, a new pasture for the poet's nostalgic imaginings. Luce Irigaray has famously argued that the foundational works of Western philosophy require a feminine backdrop against which to erect male subjectivity: 'Gardiennes de la 'nature', les femmes ne sont-elles pas celles qui entretiennent, qui permettent donc, la ressource de la mimésis pour les hommes? ${ }^{9}$ That is to say that patriarchy, which we tend to think of as hegemonic, in fact relies on what it disavows for its own construction; the male identities and privileges that purport to exclude women actually depend on them to come into being. Irigaray lays bare this gesture of foreclosure at work in the so-called 'master texts,' insofar as they need women in the elaboration of their arguments

\footnotetext{
${ }^{7}$ Adam Phillips describes the unconscious as the 'matrix of nature and the bit of nature we call culture.' [Adam Phillips, Becoming Freud: The Making of a Psychoanalyst (New Haven: Yale University Press, 2016), p. 117.]

${ }^{8}$ Pace Baudelaire’s sweeping and frequently contradictory pronouncements about woman's connection to nature and to artifice, which prompts him to deduce woman's inferiority from her supposed proximity to nature.

${ }^{9}$ Luce Irigaray, Ce sexe qui n'en est pas un (Paris: Minuit, 1977), p. 74.
} 
without ever acknowledging that debt. 'Feminine' landscapes can thus be seen to operate as a blank slate and a specular support to bolster male subjectivity. ${ }^{10}$

In A Room of One's Own, Virginia Woolf may well have asserted, to the same effect, that '[w]omen have served all these centuries as looking-glasses possessing the magic and delicious power of reflecting the figure of man at twice its natural size, ${ }^{11}$ in Baudelaire's work we nonetheless encounter the recurring motif of a gigantic woman in whose majestic body the dwarfed speaker seeks both comfort and delight. ${ }^{12}$

${ }^{10}$ Obvious comparisons can be drawn with Edward Said's arguments about Orientalism, namely that without admitting as much, the West uses the Orient to prop up an idealised image of itself.

${ }^{11}$ Virginia Woolf, A Room of One’s Own. Three Guineas (Oxford: Oxford University Press, 1929, repr. 1992), p. 45.

${ }^{12}$ A mise en abyme from Pedro Almodóvar's film Hable con ella (2002) partakes with palpable glee in this Baudelairean aesthetics of the large scale. Taking the form of a seven-minute black and white silent film called The Shrinking Man, it stages the fantastical story recounted by a hospital nurse to the comatose woman whose legs he is massaging and whom, it must be said, he has also raped. (One should also point out that the nurse's tale ends up problematising the rape that it evidently seeks to reframe and so redeem). In this jaunty sequence, we see our Lilliputian protagonist gazing amorously upon his sleeping — yet crucially still sexually responsive — female companion. After he manages to pull down the sheet that covers her naked body, he scrambles up and over the hills of her breasts and rolls down into the valley of her cleavage. His gaze, like the camera lens, is then drawn to her knees, thighs and pubic mound with its tufts of forest-like hair. The sequence ends with the minuscule hero 
The sonnet 'Semper Eadem' closes with the fanciful musings of the poet who longs to plunge into his lover's ingenuous eyes and slumber in the shadow of her lashes:

Laissez, laissez mon cœur s’enivrer d'un mensonge, Plonger dans vos beaux yeux comme dans un beau songe, Et sommeiller longtemps à l'ombre de vos cils!

Nowhere is the Baudelairean spectacle of woman qua landscape more beguiling however than in the pastoral poem 'La géante.' Narrated in the pluperfect subjunctive, the literary tense of fantasy and wistful reverie, this elegy for what never was harkens back to mythical beginnings outside historical time, transporting us to the halcyon days when Mother Nature, in her creative fervour, begat a multitude of fantastical 'enfants monstrueux,' among whom the titular giantess. The entire sonnet originates from a wish the poet formulates in the third line: 'J'eusse aimé vivre auprès d'une jeune géante,' and this embryonic phrase further spawns a series of verbs in the infinitive mood that dramatise his interaction with her. These infinitives attend initially to the gaze. First his: 'J'eusse aimé voir son corps fleurir [...] | Et grandir [...]', and then hers, which is frustratingly, and therefore all the more tantalizingly, mysterious. Would that he could '[d]eviner si son cœur couve une sombre flamme | Aux humides brouillards qui nagent dans ses yeux'. The primacy of sight soon gives way to a more playful and tactile discovery of her awesome forms. Neither a Romantic promeneur solitaire nor a city flâneur, the lyrical 'I' resembles rather a miniature topographer scrambling over the mighty curves and roaming the vast expanses of the giantess's body. His leisurely rambling, elongated by the internal rhyme of 'Parcourir à loisir,' takes on a peculiarly sensual intimacy. It also gives rise

climbing, headfirst and entirely, into the woman's vagina, where we are told he will live happily ever. 
to a blazon of sorts, in which the géante's pieds, corps, coeur, yeux, genoux and seins are variously enumerated and cut up into fetishized parts.

Metaphors throughout the poem invite us explicitly to conflate the female body with the pastoral scene. By turns parent, lover and toddler, the elusive figure of the poet imagines watching the flowering of the young giantess's body ('voir son corps fleurir'), strives to divine the reason for the mists that roll in her eyes (mood and weather merging in the 'humides brouillards qui nagent dans ses yeux'), and scales the imposing slope ('versant') of her knees. Furthermore, two parallel similes frame the poem by way of signposting the metamorphosis of woman into landscape. Whereas the last line of the opening quatrain positions the persona at the foot of the géante, 'Comme aux pieds d'une reine un chat voluptueux,' the final line of the sonnet depicts him sleeping contentedly in the shade of her enormous breasts: 'Dormir nonchalamment à l'ombre de ses seins, | Comme un hameau paisible au pied d'une montagne.' The queen's feet are thus transmuted via catachresis into the foot of a mountain, whilst the poet himself changes form from languorous cat to tranquil hamlet. This final picture of bucolic contentment (his, at least) is cleverly mirrored in the form of the last tercet, not only through the consonant cluster of soothing ' $m$ ' sounds, but also the rimes embrassées. For just as the poet — tiny infant or sated lover, one cannot tell for sure — sleeps in the shelter of the supine géante’s bosom, so too is the masculine rhyme of 'seins' nestled between the folds of the two feminine rhymes of ‘campagne' and 'montagne’.

And yet there is something slightly disquieting lurking just beneath the surface of this pastoral tableau. Jarring allusions to ‘soleils malsains,' 'terribles jeux' and a 'sombre flamme' introduce a feeling of ambivalence and even a sense of threat that jeopardise the scene’s apparent repose. Perhaps the penetrable, pliable mass of female flesh is not quite as yielding as it seems? Something doesn't quite give here: the 
enigma of female desire, for one, remains as intractable as ever. The oxymora seem to hint at an underlying anxiety regarding the status of woman — the poem's vital source and ostensibly inexhaustible natural resource — in relation to the poet's own creative potency. The sonnet is, after all, intensely concerned with matters of conception and gestation. So much so that it comes to resemble something like a competition between progenitors: consider Mother Nature's prodigious fertility, the mystery 'brooding' in her female offspring's pregnant gaze, and of course the speaker's brain-child that is this whole bucolic fantasy. But pitted against nature's 'verve puissante’ and woman’s maternal function, how does the poet’s own capacity to engender ‘magnifiques formes’ really measure up?

'La Chevelure' is one of several poems from Les Fleurs du mal that finish on a similarly anxious note. Here too woman plays muse and handmaiden to male genius. As a vessel for the poet's rapturous voyage, the lover's hair acts as the catalysing force fuelling the poem's constantly shifting imagery. Following a logic of metonymic displacement, the dark tresses morph into forest, ocean, wave and night sky, transporting the persona to distant exotic lands. The piece reaches its climactic conclusion in the suggestive image of the poet sowing precious gems ('la rubis, la perle et le saphir') in his lover's hair. (As one of many Baudelairean analogies for the poetic craft, the speaker's seminal fluid is also imagined rather more disturbingly in 'À celle qui est trop gaie,' as the venom that the speaker infuses in the woman's 'wound.' ${ }^{13}$ ) In the aftermath of the ecstatic encounter in 'La Chevelure' however, the coda's not-so-rhetorical question betrays a lingering insecurity in the poet as to who

\footnotetext{
${ }^{13}$ In a further sadistic twist to this erotic fantasy, a deep gash in the woman's side carves out a new set of labia. The wound is described as 'lèvres nouvelles, | Plus éclatantes et belles' (than the real thing, presumably).
} 
in this scene is ground, and who is figure: 'N'es-tu pas l'oasis où je rêve, et la gourde | Où je hume à longs traits le vin du souvenir?'

The topos of womanscape would seem to open up a space of vulnerability in Baudelaire's poetry even as it attempts to consolidate male mastery. This is not always so: what is effectively a pretext, in Baudelaire's work, for testing questions of connection and difference between a masculine self and the feminine other he cannot do without, becomes in Michel Tournier's novel a placeholder for that which must be forsaken upon admission into the brotherhood of men.

\section{The Woman-Island}

James Joyce once observed that the true symbol of British conquest was embodied in Robinson Crusoe, ${ }^{14}$ and Edward Said went so far as to maintain that Daniel Defoe could not possibly have conceived of his novel outside the context of European imperialism. Recent robinsonnades ${ }^{15}$ by contrast — Derek Wolcott's Pantomime (1978) and J.M. Coetzee’s Foe (1986) in English, or Martiniquais novelist Patrick Chamoiseau's Empreinte à Crusoé (2012) in French — stem from the desire to contest the values and ideas that underpin this original allegory for the colonial

${ }^{14}$ Defoe's novel 'reveals, perhaps as no other book in all English literature does, the cautious and heroic instinct of the rational being and the prophecy of the empire.' [James Joyce, 'Realism and Idealism in English Literature: Daniel Defoe \& William Blake’ (1912) in Occasional, Critical, and Political Writings, ed. by Kevin Barry (Oxford: Oxford World Classics, 2000), p. 174.]

15 The term was coined for the endless variations and rewritings that were spawned by Defoe's novel. No doubt the opportunity that the desert island story affords for reimagining the foundation of new worlds is key to its continuing popularity. 
project. Michel Tournier's acclaimed Vendredi ou les limbes du Pacifique constitutes one such subversive palimpsest. ${ }^{16}$

Tournier's work is precisely the opposite of a ‘civilising' novel. One critic quipped that it retells Defoe's classic from the perspective of Rousseau, but a Rousseau who would have read Freud ${ }^{17}$ (and, one might add, a fair dose of Aimé Césaire and Claude Lévi-Strauss too). From the very outset, the title makes plain how Tournier proposes to turn Defoe's narrative on its head. In this postcolonial, ecomythological Bildungsroman, the roles are pointedly reversed. ${ }^{18}$ In the end Robinson fails abysmally in his bid to domesticate the desert island and to subjugate Vendredi, and it is instead the Araucanian bon sauvage who comes to act as initiator to his former 'Master.' Vendredi thereby assumes the role of the pastoral's humble but wise peasant who teaches the Englishman the superiority of 'native' values and of a life mystically attuned to Nature's rhythms. (This particular version of the pastoral evidently owes much to the Césairean and Senghorian vision of négritude.) The two characters function as polar opposites: through his love of laughter and play, as well as his easy connection with animals and his surroundings, Vendredi is every bit the otium to Robinson's negotium.

If Defoe's novel, in restaging the process of civilisation from scratch, championed the virtues of capitalism, Protestantism, property, agriculture, technology

\footnotetext{
${ }^{16}$ Or should we say two, since Tournier also wrote a version of his novel for children entitled Vendredi ou la vie sauvage in 1971.

${ }^{17}$ Dominique Viart, Le roman français au XX $X^{e}$ siècle (Paris: Hachette supérieur, 1999), p. 129.

${ }^{18}$ With one important caveat being that Vendredi is not granted (much of) a voice in the novel, which is resolutely focused on the Englishman.
} 
(and, lest we forget, slavery), then Tournier's text by contrast can be read as a systematic refutation of nearly all of its founding principles. All, that is, save one, since the trope that conjoins woman and landscape remains curiously unproblematised here. Contrary to Jacques Derrida’s assertion that there is not a single trace of woman in Defoe's Robinson Crusoe — 'Pas de trace de pas de femme, ${ }^{19}$ he writes — the feminine on Tournier's island is in fact ubiquitous, starting with the personification of the shipwrecked Virginie, 'empalée sur son gros ventre, ${ }^{20}$ and epitomised by the island itself, ostentatiously gendered as female. ${ }^{21}$ What Defoe's Crusoe had christened the 'Island of Despair' is named Speranza by Tournier’s castaway, in memory of a hot-blooded Italian from his student days.

Until the arrival of Vendredi, Tournier's Robinson follows in the footsteps of Defoe's Crusoe, working tirelessly to 'administer' the island that he has dutifully claimed for the Church of England. Nothing if not diligent, the self-appointed Governor of the island devotes his energies not just to taming the wild goats, tilling the land and planting crops, but also to drawing up a charter, a constitution and even

19 Jacques Derrida, Séminaire: La bête et le souverain II, 2002-2003 (Paris: Galilée, 2010), p. 92.

${ }^{20}$ Michel Tournier, Vendredi ou les Limbes du Pacifique (Paris: Gallimard, 1967), p. 19. Henceforth, all page numbers will be indicated parenthetically in the body of the article.

21 'Il lui semblait d'ailleurs, en regardant d'une certaine façon la carte de l'île qu'il avait dessinée approximativement, qu'elle pouvait figurer le profil d’un corps féminin sans tête, une femme, oui, assise, les jambes repliées sous elle, dans une attitude où l’on n’aurait pu démêler ce qu'il y avait de soumission, de peur ou de simple abandon.' (46) 
instating a form of currency on his isle of one, thus unwittingly exposing, if need be, the insanity that lies at the heart of instrumental reason. Yet his delusional drive to colonise is thwarted by the desert island that beckons to him at every turn. This appeal of the earth, described as the 'telluric' phase in Robinson's development, gives us an important glimpse into the distinct roles that Tournier's novel ascribes to the sexes.

The Telluric Phase (stage one): Speranza as Mother

Following his regression to a bestial state when he is first marooned on the island and which sees him grazing on all fours and wallowing in the muck of the souille, Robinson takes to retreating to a dark cave where he remains for hours on end, 'suspendu dans une éternité heureuse' (106). The cave’s likeness to a womb is blatant: the naked hero moves into the tunnel as if along the smooth walls of the birth canal into a warm, damp cavity where he curls up in the foetal position in a state of sheer bliss.

As if predating individuation, Robinson's return to homeostasis is virtually indistinguishable from death: womb and tomb are one and the same thing. It is fitting then that as with the earlier episodes in the primeval muck (and unlike many episodes that follow this interlude and are recounted by Robinson in his logbook), the protagonist's visits to the grotto-womb are narrated exclusively in the third person. This loss of self is but one of the unintended side effects produced by the 'monstrous maternal vocation' that Robinson assigns to Speranza. In the grips of a drought, the island refuses its usual bounty; the protagonist deduces that Speranza's 'menstrual flow' has been interrupted during her 'pregnancy' with him. Robinson's manly vigour is likewise diminished, and he appears thoroughly emasculated, not to say castrated — 'Son sexe humilié avait fondu’ (110) — when he exits the cave. 
Gaston Bachelard and Juri Lotman give special consideration in their semiotic analyses to spaces that are construed as maternal and feminine. These immobile spaces that offer shelter and spiritual sustenance do not generally possess a function or meaning of their own but rather serve to produce meaning for another. This is what Teresa de Lauretis calls a 'rhetoric of violence':

As [the hero] crosses the boundary and 'penetrates' the other space, the mythical subject is constructed as human being and as male; he is the active principle of culture, the establisher of distinction, the creator of differences. Female is what is not susceptible to transformation, to life or death; she (it) is an element of plot-space, a topos, a resistance, matrix and matter. ${ }^{22}$

To which we might add Irigaray’s words: ‘La mère-matière-nature doit encore et toujours nourrir la spéculation. Mais cette re-source [sic] est aussi rejetée comme déchet de la réflexion, mise à l'extérieur de ce qui lui résiste: comme folie. ${ }^{23}$ And so in the caverns and fortresses that house and nurture the male protagonists who are subsequently compelled to renounce them, the feminine is left yet again to do the symbolic labour of conception whilst reaping none of its benefits.

The Telluric Phase (stage two): Speranza as Lover In a second stage of the telluric phase, Speranza's role as mother changes to that of lover, and a vulvar pink combe, rather than the uterine cave, becomes the focal point of Robinson's tender ministrations. All 'plis accueillants' and 'ondulations lascives' (175), Speranza coquettishly lifts her dirt dress to reveal a flash of nipple or her

${ }^{22}$ Teresa de Lauretis, Technologies of Gender: Essays on Theory, Film, and Fiction (Basingstoke and London: Palgrave Macmillan, 1987), pp. 43-4.

${ }^{23}$ Irigaray, Ce sexe qui n'en est pas un, p. 74. 
musky tufted mound. ${ }^{24}$ So titillating proves the woman-island that Robinson cannot help but make love to her, lying naked atop 'cette gigantesque et brûlante femelle pour la labourer d'un soc de chair' (175). Angela Carter's observations about the missionary position in The Sadeian Woman could hardly be more germane:

The missionary position [...] implies a system of relations between the partners that equates the woman to the passive receptivity of the soil, to the richness and fecundity of the earth. A whole range of images poeticises, kitschifies, departicularises intercourse, such as wind beating down corn, rain driving against bending tress, towers falling, all tributes to the freedom and strength of the roving, fecundating, irresistible male principle and the heavy, downward, equally irresistible gravity of the receptive soil. ${ }^{25}$

Their novel copulations introduce new vegetation on the island as mandrakes — the roots of which conjure up the body of a girl — suddenly blossom around the combe. He notes with great satisfaction that 'ses amours avec Speranza n'étaient pas demeurées stériles: la racine charnue et blanche, curieusement bifurquée, figurait indiscutablement le corps d'une petite fille' (137). Notice how the adverb indiscutablement here, as in the description of Speranza as 'une personne, de nature indiscutablement féminine' (101-2, emphasis in original), places the rhetorical feminisation of nature beyond dispute. Just as indisputable, evidently, is the virgin / whore dichotomy within which Speranza is firmly ensconced, since no sooner does Robinson recognise the mandrakes as his very own 'daughters' than striped

\footnotetext{
${ }^{24}$ The island is said to have 'écarté sa robe de terre,' revealing 'sa toison balsamique' (175) and her 'mamelon de terre' (113).

${ }^{25}$ Angela Carter, The Sadeian Woman and the Ideology of Pornography (New York: Pantheon, 1978), p. 8.
} 
mandrakes also begin to bloom nearby: damning proof that Vendredi has defiled his beloved 'bride,' and worse still, that the 'terre adultère' (177), discovered in flagrante delicto, is complicit in 'fornication' (179).

The Big Bang: The Solar Phase

Life on the island changes irrevocably when Vendredi, who had been illicitly smoking Robinson's pipe in the cave, sets off an explosion that destroys the Englishman's settlement. Paving the way for Robinson to begin afresh, this tabula rasa ushers in the Golden Age of the 'règne solaire’. Under Vendredi’s aegis, Robinson will evolve from the debased horizontal plane of the telluric phase, mired in abject inert feminine matter, to the nobler solar realm, embodied in the dynamic vertical motifs of light and flight.

Robinson's rebirth also clearly marks the shift from a (failed) Utopia, predicated on the notion of the perfectibility of homo laborans, to the advent of Arcadia, where Vendredi models a more intuitive and authentic way of being in, and cosmically at one with, the world. As in the pastoral, time appears magically suspended. The hours and days that Robinson had hitherto so urgently measured with his water clock now give way to the expanded experience of Bergsonian durée. To be sure, the sustaining pleasures of an eternal present are precisely what seal Robinson's decision to remain on the island when the Whitebird alights on Speranza's shores, a full twenty-eight years after the shipwreck of the Virginie: 'Il n'allait pas s'arracher à cet éternel présent, posé en équilibre à la pointe d'un paroxysme de perfection, pour choir dans un monde d'usure, de poussière et de ruines!' (246). And yet this emphasis on dwelling in the present moment is continually undermined by the teleological thrust of Robinson's narrative that charts his purposeful progression from the socalled 'telluric' to the 'solar' realms. 
Goats, those stalwart creatures of the pastoral, also set the bucolic stage for the protagonist's development. Long swathes of Defoe's text are dedicated to their taming and husbandry, and in Tournier's novel the first living being Robinson encounters on the desert island is a goat (which he summarily kills). Following the death of another billy goat, Vendredi rather cryptically announces to Robinson that soon the great goat Andoar shall fly and sing again. Akin to the Pan flute-playing goatherds of Theocritus and Virgil, Vendredi turns the animal carcass into a kite and an Aeolian harp. His joyful pursuits of freedom, music and play stand in sharp rebuke to the instrumental logic that had once motivated Robinson's colonial enterprise.

Along with this solar realm comes a pansexual, polymorphous form of desire. Given that his erotic impulses are no longer enclosed within a genital paradigm, let alone shaped by those 'institutions et [...] mythes qui permet[tent] au désir de prendre corps, au double sens du mot, c'est-à-dire de se donner une forme définie et de fondre sur un corps féminin’ (118), Robinson’s ‘elemental’ sexuality now allows him to circumvent the female form entirely. For he and his companion are emancipated as much from the contingencies of History as from the limits of sexual difference: 'En vérité, au suprême degré où nous avons accédé, Vendredi et moi, la différence de sexe est dépassée [...]' (230).

And so the tensions that had arisen between male rivals in the telluric phase soon dissipate, while the female 'body' of Speranza that had brought them together in the first place recedes into the background, relegated to her status as mere theatre for a drama that unfolds wholly between men. What is more, the homosocial bonding of Robinson and Vendredi leads to their doubling in the guise of 'gémeaux solaires' (the theme of twinning courses through Tournier's oeuvre). Robinson writes in his logbook: 'il est pour moi toute l’humanité rassemblée en un seul individu, mon fils et mon père, mon frère et mon voisin, mon prochain, mon lointain’ (224). The 
conclusion of the novel sees the concurrent departure of Vendredi on the Whitebird and arrival of Jaan, an Estonian galley-boy, red-headed just like Robinson, who elects to stay on the island and whom Robinson renames Jeudi.

Robinson thus (re)produces a son in his and Vendredi’s image. Conveniently occurring without the intervening assistance of a woman, this process of replication enters into consonance with Irigaray’s analysis of philosophy’s simultaneous suppression of, and unconscious dependence on, the mother. In one of the most compelling chapters of her book Speculum, Irigaray uncovers this erasure of the maternal feminine in Plato’s myth of the cave, or more exactly the hystera, a term she chooses the better to underscore the cave's link to the womb. The feminist philosopher reads Plato's allegory as a kind of fantasy primal scene in which the role of the cave-mother is devalued and effaced in favour of the solar-father, who becomes the sole origin of concepts. (The word concept is itself far from innocent of course, and Irigaray is keen to remind us that the co-opting of the maternal function is in the very language that we use.) In Vendredi ou les limbes du Pacifique, the fantasy of male parthenogenesis is two-fold, in that it excludes women from the process of conception at the same time as it denies biological difference. If, as a result, Tournier's anticolonial critique is not quite as 'groundbreaking' as it at first might appear, this is no doubt because the mystifications of womanscape continue to ground, in an apparently straightforward fashion, the author's speculations.

\section{The Woman-Nation}

After the woman-mountain and the woman-island, let us turn to the woman-nation in Ivan Jablonka's Laëtitia ou la fin des hommes. Such is the lability of the womanscape trope that the mapping of the body politic onto a female body should come as no 
surprise. Examples of this rhetorical manoeuvre abound: ${ }^{26}$ we need only think of the French Republic, which finds one of its most enduring icons in the Phrygian-capped Marianne, whose bare breasts (the better to suckle the masses) were invoked by Prime Minister Manuel Valls in the infamous 'burkini row' in the summer of 2016. In Ivan Jablonka's account of a fait-divers that gripped the French nation in 2011, the historian probes one of the more disturbing uses of this topos in recent years.

The woman in question, Laëtitia Perrais, was an 18-year old waitress from the seaside resort of Pornic in Brittany who was stabbed, strangled and dismembered on the night of 19 January 2011. Tony Meilhon, a 32-year old drifter with over a dozen crimes and misdemeanours to his record, was arrested and charged with her murder two days later. Although the boot of the car he had stolen was drenched in Laëtitia's blood, it would take another three months for her severed body parts to be recovered.

The affaire Laëtitia proved exceptional not merely for the intense media interest that it generated during that time, making front-page news for six weeks and prompting mass outpourings of grief both on social media and in televised vigil marches, but for the then President's unprecedented intervention in judicial matters, ${ }^{27}$ which Jablonka excoriates as opportunistic scaremongering. By exploiting Laëtitia’s

${ }^{26}$ In the case of France, see for example Agrippa d'Aubigné’s epic poem Les Tragiques (1616), which depicts his war-torn homeland as a 'mère affligée' whose body is being savaged by her feuding infants. French Catholics also commonly refer to their country as the 'eldest daughter of the Church.'

${ }^{27}$ Sarkozy's extraordinary scapegoating of judges led to the strike of 8000 court magistrates. Jablonka’s book is as much an homage to Laëtitia's strength and vitality as it is an impassioned defence of the investigating judges, clerks of the court, police and probation officers who sought justice for her. 
case whose facts he had misrepresented, Nicolas Sarkozy succeeded in introducing a series of far-reaching repressive measures in the name of law and order. ${ }^{28}$ Beyond the violence inflicted on Laëtitia throughout her short life and which culminated in her brutal killing, it is this instrumentalisation of her death for political ends that is, in Jablonka’s eyes, most grievous. Provocatively, he goes so far as to accuse Sarkozy of doing to the body politic what Meilhon had done to Laëtitia:

Les mots ont été, dans la bouche de Nicolas Sarkozy, comme la scie à métaux entre les mains de Tony Meilhon: un instrument de découpe, un tranchoir. Ses discours ont été un acte de division; la société en est ressortie toute sanglante. C’est en ce sens que, par-delà l’émotion suscitée par sa mort, Laëtitia incarne la France. Pendant l’hiver 2011, elle a prêté son corps à une démocratie. ${ }^{29}$ Whether condemning the myriad father figures who battled for control of the deceased woman's image, ${ }^{30}$ or the systemic violence perpetrated against women, Jablonka puts gender at the forefront of his critique.

At first blush then, Laëtitia ou la fin des hommes could not seem further from the pastoral. Fait-divers items commodify tragedy by turning it into a spectacle for mass consumption, and one would be hard-pressed to think of a form more inimical to

${ }^{28}$ These ranged from minimum sentencing and secure detention to the broadening of the definition of recidivism and the recourse to lay juries in criminal cases.

${ }^{29}$ Ivan Jablonka, Laëtitia ou la fin des hommes (Paris: Seuil, 2016), p. 264.

Henceforth page numbers will be listed in the body of the article.

30 ‘Ce chassé-croisé de vrais pères, de faux pères, de pères symboliques, de pères de substitution, cette mise en scène de l'autorité a pour enjeu l'appropriation de l'icône Laëtitia.’(138) 
bucolic themes and imagery. ${ }^{31}$ Yet it is my contention that Jablonka's approach to this crime story, as well as his portraits of Laëtitia and of a society in crisis can be better understood through reference to the pastoral elegy, whose procedures and motifs his work rehearses from the start. Jablonka thus endeavours to separate Laëtitia from the sensationalist narrative surrounding her death, and in so doing, to extricate her from Sarkozy’s politically expedient rhetoric. As he succinctly puts it, 'Laëtitia n’a pas vécu pour devenir une péripétie dans la vie de son meurtrier, ni un discours à l'ère Sarkozy’ (10).

'How can a modern poem fulfil the office of pastoral elegy, of speaking for the dead to the fellow humans who survive her? ${ }^{32}$ asks Paul Alpers in his discussion of the pastoral as a life-giving form. Central to Jablonka's project is precisely this desire not simply to lament Laëtitia's untimely death but also to reanimate her ('lui rendre sa vie'), to restore the agency and dignity of which her murder had deprived her, while at the same time paying tribute to her twin sister Jessica’s courage and forbearance in the face of unspeakable traumatic loss. The book opens with a Latin quotation from Spinoza's Ethics ${ }^{33}$ that aptly reminds us of the meaning of Laëtitia's name — delight, happiness — and from this epigraph onwards Jablonka emphasises Laëtitia’s vivacity, resilience and capacity for joy. With unimpeachable rigour and

\footnotetext{
${ }^{31}$ It is tempting to turn once again to Baudelaire, whose prose poems in Spleen de Paris, by contrast with the lyricism of Les Fleurs du mal, assimilate the ironic tone and lurid subject matter of modern journalism and mass entertainment. ${ }^{32}$ Paul J. Alpers, What is Pastoral? (Chicago: University of Chicago Press, 1997), p. 270.
}

33 'Laetitia est hominis transitio a minore ad majorem perfectionem.' ['Joy is man's transition from a lesser to a greater perfection.’] 
tact, the author consulted her family, friends and workmates as well as those involved in all aspects of her case. What emerges from these interviews is the picture of a kind, caring ‘jeune fille radieuse aimée de tous’ (9), who against all odds had overcome tremendous adversity and was quietly determined to make her way in the world. Indeed Jablonka is at great pains to show that in spite of a childhood riven by parental abuse, neglect and addiction, followed by several years spent in care, Laëtitia was not, or never exclusively, the victim that the media made her out to be: 'Laëtitia n'est ni Cosette traînant son seau, ni la servante Félicité entichée de son perroquet. Au milieu des difficultés en tous genres, elle s’est battue’ (218).

This goes some way towards explaining Jablonka's turn towards the pastoral, his deliberate adoption of its tropes and genteel turns of phrase in the hope of guarding Laëtitia’s story against both the tawdry frisson of tabloid journalism and the clinical detachment of forensic reports. He singles out for especial praise the public prosecutor, Xavier Ronsin, whose sensitive presentation of the case chimes closely with his own:

Ses mots visent à redonner à Laëtitia sa dignité. Pour ne pas la réduire à des morceaux de cadavre, à une trouvaille macabre, il parle de 'la jeune femme sortie de l'eau', comme une naïade en fleur, une Vénus née de la vague. Quand il évoque la partie du corps manquante, il dit 'le buste’, avec sa connotation d'élégance et de charme, alors que tout le monde pense à un tronc, un parallélépipède de chair mutilée. À son exemple, tous les journalistes se mettent à parler du 'buste'. Malgré l'urgence de l’information, la course à l'audimat, le formatage du vocabulaire, chacun déploie le langage comme un linceul de délicatesse. (165)

Acting as veils of discretion, these euphemistic allusions to Laëtitia's buste and to her figurative afterlife as water nymph or Roman goddess contrive to replace brute facts 
with more ethereal images of sculpted statues and mythological figures, as if to suggest that art and myth might exist ready-made in nature. Jablonka similarly strives to ennoble the crime scene through pastoral personification. Using the passive voice and reflexive verbs in an extravagant outpouring of Romantic imagery, he intimates that the Breton landscape, endowed with human emotion and intention, is deeply moved by a tragedy that it is powerless to redress: 'Des marais sauvages ont été troublés, des tapis de fleurs ont été piétinés. Des ruisseaux se sont arrêtés, des puits se sont ouverts, des joncs se sont inclinés, et c’était en vain, et il n’y avait rien, la jeune fille était nulle part’' (251).

This is not to say that Jablonka relies on the pastoral mode alone. He also goes about his task of empowering Laëtitia by fleshing out the historical and socio-political contexts of the fait-divers, for example reviewing matters of jurisprudence to highlight girls’ exploited labour, or surveying past centuries for traces of modern attitudes towards the poor. The broader significance and resonance he draws from Laëtitia’s story transform it, and by extension her, into a synecdoche for $21^{\text {st }}$-century social deprivation in semi-rural France. In his analysis, Laëtitia comes to embody the country’s lumpen underclass as well as the vulnerability of women everywhere. Therein lies the double bind that Laëtitia ou la fin des hommes must negotiate, as it holds in perpetual tension both the crime story and the pastoral elegy. For paradoxically, the more Jablonka insists on the 'situatedness' of this fait-divers, the more he pulls the figure of Laëtitia towards ever greater abstraction. The chapter devoted to the question of 'feminicide' is shot through with awareness of the privileges that the author's masculinity affords him, forcing him to question his own complicity in the process of reification that he has set out to dismantle: 'Or figurer dans un livre, s’y voir objectivé, disséqué, interprété, livré au public, c’est une forme de violence' (336). At issue here is the extent to which he can raise larger socio- 
political questions while still attending to Laëtitia's singularity, to this woman and this life.

\section{Class relations}

This tension is particularly conspicuous in Jablonka's meditations on social class. Empson's reading of the pastoral centres on the encounter between the culturally sophisticated aristocrat on the one hand and the humble uneducated peasant on the other, ${ }^{34}$ a confrontation that plays an integral part in Laëtitia ou la fin des hommes. Jablonka broaches questions of social inequality primarily through his interlocutors' different levels of linguistic competence. (Such is the premium placed on éloquence in French culture that it is almost impossible to overstate the importance given to expression skills.) Jablonka’s descriptions evince the enormous disparity in symbolic capital between the classes. For instance Laëtitia's profoundly inarticulate biological father (and erstwhile convict) Franck Perrais, whose incoherent syntax is said to mirror his chaotic existence, is clearly at variance with Gilles Patron, the foster carer (later found guilty of sexual assault on minors, including on Laëtitia’s twin Jessica), who expresses himself with consummate ease and thus commands the public’s respect and sympathy in the wake of Laëtitia's death. To be sure, as a privileged Parisian intellectual possessed of an exceptional command of his mother

34 'The essential trick of the old pastoral, which was felt to imply a beautiful relation between rich and poor, was to make simple people express strong feelings (felt as the most universal subject, something fundamentally true about everybody) in learned and fashionable language (so that you wrote about the best subject in the best way.)' [Empson, p. 11.] 
tongue, Jablonka is not exempt from these power dynamics, a fact that does not go unglossed in his narrative.

Indeed the rift between linguistic mastery and insecurity is most vividly conveyed in the 'dialogue' between the author and his book's eponymous subject. Social workers who supported the twins when they were placed in care, first in an institution and then in a foster home, report Laëtitia's early difficulties in verbalising her thoughts and feelings, problems that later manifested themselves in her stammer and dyslexia. The vagaries of Laëtitia's spelling are described charitably by those who knew her as an endearing quirk, 'une gracieuse idiosyncrasie’ (86). The antiphrastic idiomatic expression that Jablonka uses to underscore the strangeness of her orthography — ‘c'est tout un poème’ (86) — is telling, since he is prone to aestheticise these mistakes for touching and at times even lyrical effect. If elegy springs from the figure of prosopopoeia, then Jablonka may be said to give voice to the deceased Laëtitia by quoting verbatim from her error-strewn Facebook posts, text messages and barely intelligible hand-written notes. Although no doubt well meaning, the author's valedictory wish is especially striking in this respect. Thinking of the swimming hole in which Laëtitia's torso was found, he writes:

[...] je voudrais que le Trou bleu soit non pas le tourbillon où l'on sombre, où l'on se noie tandis que les hommes bavardent sur le pont [...], mais le lac émeraude dont les eaux calmes et pures fixent l'attention du promeneur qui s’est assis, l’âme en paix. Comme le disait Laëtitia dans une de ses lettrestestaments et avec la poésie qui lui appartient, "la vie est fête comme sa”. Oui, comme ça, la vie est fête. (366) 
This lyrical coda is deeply embedded in the pastoral mode, with its description of idyllic scenery ${ }^{35}$ and its sweet and simple heroine featuring as the bearer of unwitting truth. From the young woman's confusion in writing 'that's just what life is like', Jablonka extracts a poignant carpe diem: 'life is a celebration that way.' Unlocking this secret knowledge concealed in her tortured spelling and artfully disclosing it for his readers’ benefit, he arrogates himself the role of Laëtitia’s benevolent interpreter.

Womanscape and the allegorical drift What might one usefully deduce from this constant reciprocal entanglement of nature and the feminine? Ranging over three centuries and as many genres, the eclectic array of examples I offer here testify first of all to the trope's extraordinary capaciousness.

${ }^{35}$ For the most part, Jablonka's presentation of the conurbation beyond which Laëtitia never travelled belongs squarely to the counter-pastoral tradition. Once-bucolic landscapes and seascapes are imbued with pathetic fallacy, as toxic waste contaminates the soil and corpses from cold cases lie at the bottom of mercury-filled ponds. Even the idyllic fairy-tale setting is tinged with sinister undertones, thanks to the nearby medieval castle of Gilles de Retz, the wealthy baron accused in 1440 of having abducted, tortured, and murdered more than 140 children (and believed to be the inspiration for Charles Perrault’s Blue Beard). Jablonka repeatedly, if a little earnestly, juxtaposes details of the grisly crime scene with its beautiful surroundings: Au procès, on montrera aux jurés et aux journalistes une trentaine de clichés: l'étang bucolique, la belle nature alentour, l'eau verte où se penchent les arbres, le chemin de terre, la falaise. Les photos prises au fond de l'eau, gros plans imprécis en noir et blanc, laissent deviner le contour des membres — une échographie de la mort. (162) 
As an enabling fiction for the stories we tell about men and women and their respective place in the world, it is part of a larger cultural conversation about how we organise space and conceive of the roles and relationships of those who inhabit it. The trope's performative force is matched by its affective charge. And this is to say nothing of the way the persistent conflation of woman and landscape effectively inscribes agency, power and politics under the sign of the masculine.

One of the chief differences between these three texts lies in the varying degrees of knowingness with which the topos is deployed. In Baudelaire's poetry, we find one of its most economical and whimsical iterations, with the distortion of scale throwing into starker focus the poet's own vulnerability. The feminised landscape in Tournier's novel, if not exactly a blind spot — to be fair, the telluric phase of Robinson's development has all the subtlety of Almodóvar's 'Shrinking Man’ clip in Hable con ella - at the very least obscures women from view. Notwithstanding its protagonist's claims of transcending sexual difference, ultimately Tournier’s robinsonnade leaves intact the gender binary and the structure of subordination it entails. Jablonka's far more critical interrogation of the trope, meanwhile, is intimately linked to his indictment of patriarchy and of Sarkozy’s self-serving discourse in particular. And yet however much Jablonka decries the objectification of Laëtitia Perrais, he finds himself having to borrow the very same strategies he denounces in order to make his point.

Whatever the aims and intentions of their authors, in each case we see the 'feminine' being marshalled in the service of something and someone else. The problem with this allegorical drift that constantly threatens to engulf the figure of woman has as much if not more to do with structure as with content. For surely what counts in the end is not merely what the pastoral topos of womanscape contains, but our expectation that the feminine serve as a container in the first place. 